\title{
Analysis of the Path of Spreading Red Culture by Film and TV Works in the New Era
}

\author{
DeMin $\mathrm{He}^{1, *}$ WenHui $\mathrm{Li}^{1}$ Yue $\mathrm{Li}^{2}$ \\ ${ }^{1}$ Media technology of Liaocheng University, Liao Cheng, Shan Ddong, China \\ 2 Daokoupu primary school, Liao Cheng,Shan Ddong, China \\ ${ }^{*}$ Corresponding author. Email: 7269516@q.com
}

\begin{abstract}
In terms of the red culture under the leadership of the Communist Party of China, it refers to the abstract sum that influences the thinking patterns and behavior patterns formed and developed in the long-term revolution, construction and reform, which is under the guidance of Marxist theory, takes the communism as the goal, takes the people as the main body and the new democratic revolution as the beginning. There is no doubt that the features of film and television works have special significance to the spreading of red culture. In this thesis, it makes combination of the film and television works's advantages of spreading culture to carry out the discussion on how the spreading of red culture takes advantage of the film and television industry from five aspects, such as perfecting the marketization mechanism system of film and television industry, the selection of red symbols, the creation of film content, the spreading path of omnimedia and the development of campus red film activities.
\end{abstract}

Keywords: Movies, Red Culture, Creative mode, Propagation path

\section{INTRODUCTION}

As pointed out by General Secretary $\mathrm{Xi}$, "It is necessary to make good use of red resources, carry forward the red tradition, and carry on the red gene." Red culture has a specific political connotation and value meaning in our country. The value spirit contained in it is the vane of China's mainstream values, the cornerstone of cultivating cultural confidence and the spiritual driving force for soul-building and education. As a media that is easily acceptable by the public, film and television works have great significance to the promotion and inheritance of red culture. In the context of the new era, effective combination of film and television works and the dissemination of red culture has far-reaching significance for the path selection of the current red culture dissemination of film and television works.

\section{THE VALUE OF TIMES OF SPREADING RED CULTURE}

Red culture is a theoretical awareness culture formed during the revolution, construction and reform by the people of all ethnic groups led by the Chinese Communist Party. It is a concentrated expression of the core values of socialism and a mainstream social concept and value system that people of all ethnic groups in the country should adhere to and practice. Inheriting and carrying forward the spiritual connotation of red culture, protecting and developing it, is of practical significance for realizing the great Chinese dream in the new era.

\subsection{Spreading red culture helps consolidate ideology}

In the post-truth era, it is getting more and more difficult for the audience to obtain the truth. The truth can be processed into one-sided truth, subjective truth, manmade truth and unknown truth. Audiences are often unable to distinguish true from false among the massive amounts of information and polarized subjective emotions, and therefore gradually loss their subjectivity. Red culture is a political symbol that spontaneously and consciously formed in history and reality and is vividly displayed. It has witnessed the practice process of Marxism in China and is an important part of China's mainstream culture. The ethical, moral and political rules demonstrated by it shows the advanced nature of culture and meet the expectations of the general public. The spirit of sacrifice, fighting and democracy contained in it can play an ideological leading role in the current society. In the context of the new era, it is even more necessary to 
take another look at the profound connotation and value of times of the red culture, and let it play a role in providing identity guarantee and consolidating ideology.

\subsection{Spreading red culture can help strengthen cultural confidence}

As pointed out by General Secretary Xi Jinping, "Cultural confidence is a more basic, much deeper, and more lasting force in the development of a country and a nation." ${ }^{[1]}$ Cultural confidence is built on the basis of cultural soft power which cannot be improved without the dissemination of red culture. Effective dissemination of the red culture not only helps to shape the image of our country, but also enhances the international discourse power of the country while enhancing the international influence of Chinese culture. The red culture is rooted in the excellent traditional Chinese culture which gives new connotations and dialectical relationships to the red culture at the same time. The red culture has strong cohesion and attractiveness and is the source of strength for the great rejuvenation of the Chinese nation. Spreading red culture is to promote our national spirit, inherit national historical memory and value cognition. In the context of the complex interweaving of multiple cultures, we should not only pay attention to the glorious past of the spread of red culture, but also examine the current situation of its inheritance and development.

\section{THE ADVANTAGES OF SPREADING RED CULTURE BY FILM AND TELEVISION WORKS}

As a theoretical consciousness, the red culture will not be naturally understood, accepted, recognized and practiced by people. It needs a conversion or effective dissemination path, so that members of society can form a generally consistent system of concepts, values and social norms which will act as a universal force that promotes the development of society. ${ }^{[3]}$ The life-oriented characteristics of film and television works are more likely to arouse the empathy from the audience. From the perspective of cultural semiotics, the meaning of red culture is constructed by the audience' $\mathrm{s}$ viewing of film and television works and interpreting the discourse relationship of such works. The construction of such a discourse relationship is also a process from symbol production to symbol reception and interpretation. Based on the understanding of the connotation of red culture, the disseminators use audio-visual language as the means to spread the essence of culture through symbolic representation, reproduction, reconstruction and other forms, which result in the appearance of a specific meaning.

\subsection{Spreading red culture by film and television works is a smart choice in the context of the new era}

Film and television works are the integration of artistic expression and ideological concepts. They have unique effects in expressing and disseminating humanities and arts, social features, and cultural history. ${ }^{[2]}$ They undertake the important missions such as the dissemination of national images, international cultural exchanges, and historical and cultural interpretation. Film and television dissemination is a collection of sounds, pictures, images and other symbols. Compared with traditional single dissemination means, such as books, objects, explanations, film and television dissemination can give the audience a strong audiovisual shock, showing great artistic appeal and better dissemination effects. At present, with the rapid development of the Internet technology, new technologies such as big data, the Internet of Things, cloud computing, and mobile Internet have been widely used in the film and television industry. Various new media have emerged as the times require, such as video websites, IPTV, and mobile TV. Film and television dissemination has obtained unprecedented opportunities for development and has become an effective way of knowledge construction, cultural exchanges, and educational publicity. In such a trend, using film and television dissemination to inherit and develop the red culture is the best choice to give the red culture new life.

\subsection{Film and television works can break the time and space boundaries in the spread of red culture}

With the continuous development of the times, many red cultural heritages have disappeared in the long river of history. Due to the constraints of time and space, the spread of red culture can only be carried out within a specific time and space, which restricts its spread. In the modern media society, time and space barriers are constantly being broken, and film and television works have created a space for cultural inheritance that transcends time and space. The disseminators use scene symbols for reproduction, which truly restores the red deeds that have occurred. At the same time, as a medium language for communication and interaction, film and television works can realize interactive communication between audiences and producers. Moreover, the audience coverage in the film and television field is wider, and there is not such a high requirement on the audience's education level, cultural level, appreciation ability, etc., which are the great advantages of film and television works in the process of cultural dissemination. 


\section{CONSTRUCTION PATH OF RED CULTURE BY FILM AND TELEVISION WORKS}

\subsection{Perfect the marketization mechanism of the film and television industry}

If the spreading of red culture needs to rely on film and television works, it should firstly guarantee that the film and television industry has everlasting vitality. In view of it, we have the necessity to perfect the marketoriented system and mechanism of film and television industry, in which the premise is to give full play of the fundamental role of market allocation of cultural resources. ${ }^{[4]}$ When it comes to the government, it is necessary to issue special support policies, so as to start from the aspects of law and system to provide a good development environment for the film and television industry. Then, it has the necessity to create the necessary conditions for the prosperity of the film and television industry according to the economic norms of market, which should also bring the film and television culture industry into the legal track, avoid the appearance of the chaos of the film and television industry from the source, as well as ensure its sustained, efficient and stable development. Furthermore, it has the necessity to perfect the basic cultural and economic system for film and television industry. On the other hand, the government has the necessity to make combination of the resource situation and development reality of its own film and television industry, which should cooperate with the legislature by complying with the country's major policies, and formulate the cultural and economic system fit for the development of the local film and television industry by referring to the market system, so as to make sure that the film and television works as well as the links of creation, promotion, and dissemination can be completed in a reasonable and orderly manner.

\subsection{Selecting symbol content with red cultural significance}

Red cultural education should enable people to intuitively understand the deep meaning behind the symbols through their perception of the symbols. The symbol carriers for carrying and disseminating red cultural thoughts are divided into material symbol carriers, institutional symbol carriers and spiritual symbol carriers. The material symbol carrier is the red cultural artifact, which is the external material manifestation of the red culture and is presented by its physical shape and structural form, including the relics used by the revolutionary martyrs and the ruins of the revolutionary war. ${ }^{[5]}$ The institutional symbol carrier is the theory, program, line, policy, system, etc. formed by the Chinese Communist Party in different historical periods of revolution, construction and reform practice.
The spiritual symbol carrier is the red spirit formed by the Chinese Communist Party in the revolution, construction and reform, such as the spirit of the red boat, the spirit of the red flag canal, and the spirit of manned spaceflight. We need to develop the red resources and enhance the completeness of content narration. The key to the dissemination of red culture lies in the completeness and comprehensiveness of the content. Therefore, it is necessary to develop red cultural resources in depth. On one hand, it is necessary to look at the history of the development of red culture in a correct and comprehensive way, and not to completely deny the red culture because of some twists and turns, nor to ignore the existing problems because of the great achievements. On the other hand, red cultural resources must be organized systematically and in-depth, making history connect with reality.

\subsection{Paying attention to the dissolution of red culture in film and television works}

Although the Internet era has greatly improved the efficiency of red culture dissemination, the film and television industry still cannot get rid of the dilemma of entertainment driven. ${ }^{[6]}$ Users are driven by capital and flow to meet the entertainment needs of the public. On one hand, entertainment videos are still the mainstream products on the platform, which the influence of red culture videos cannot compare with. On the other hand, the pan-entertainment attributes of the film and television industry make red culture unable to get rid of the dilemma of being entertaining or even vulgarized and debased. Many red classics are created as spoof videos. There is a huge gap between the final products and the high-quality content of red classics, and the final products do not have high aesthetic value and spiritual connotation. In this process, the red cultural classic content is continuously deconstructed, its comprehensiveness, integrity and coherence are broken, and it is decomposed into some raw materials separated from the spiritual connotation of red culture, which may reduce the red culture into a kind of cheap audio-visual material. Its spiritual core is constantly lost in the production process, which eventually leads to the hollowing of the red culture.

\subsection{Expanding the export channels of film and television works with the concept of "all media".}

General Secretary Xi Jinping proposed to "form an all-media dissemination system with intensive resources, reasonable structure, differentiated development, and coordination and efficiency."The external dissemination of Qilu Culture must integrate online and offline resources, concentrate on improving the main platform, expanding the main channel and strengthening the main account, and establish an all-media dissemination matrix with intensive resources, collaboration and efficiency, innovative methods, and linkages between internal and 
external propaganda. ${ }^{[7]}$ It is necessary to comprehensively use various media to innovate and promote the use of film and television works to spread the red culture. In addition to traditional movies and television, we can use new media such as public platforms and self-media to produce mobile, visualized, and socialized communication products, and apply cutting-edged technologies such as big data, cloud computing, and artificial intelligence to the collection, production and distribution of red culture information. The role of new media should be fully brought into play to allow audiences and disseminators to communicate in a timely manner and accelerate the spread of red culture in the new era. This will not only satisfy the audiences in communication and information feedback, but also produce a secondary cultural dissemination.

\subsection{Strengthening the red cultural education of film and television in primary and secondary schools}

Schools are the important grounds for the development of youth red education. General Secretary $\mathrm{Xi}$ Jinping emphasized that "evolutionary traditional education should start from the children, and it should focus not only on instilling knowledge, but also strengthening emotional cultivation, so that the red gene can penetrate into the blood and heart and guide the vast number of young people to establish the correct views on the world, life, and values." Conducing red cultural education in primary and secondary schools is an important way to promote the inheritance of red gene, cultivate and practice the core values of socialism. ${ }^{[8]}$ It is also a powerful means to implement the fundamental task of morality education and help young people button up for the first time in their lives. Schools can offer red education courses, red movies and televisions on campus. In this way, schools can strengthen students' knowledge and understanding of red culture, make them understand the history of their own country, learn from revolutionary ancestors and pioneers, and practice the core value of socialism in person. ${ }^{[9]}$ Schools should vigorously promote the national spirit with patriotism as the core, tell the story of socialism with Chinese characteristics in the new era well, guide students to adhere to the correct political direction, strengthen their cultural confidence, and play a positive role in creating a harmonious and progressive cultural atmosphere on campus.

\section{CONCLUSION}

Generally speaking, new challenges are brought to the spreading of red culture with the rapid development of the film and television industry. However, it should stand at a higher level to carry out the theoretical thinking. When it comes to the spreading of red culture, it should distinguish different audience groups, accurately apply communication strategies and communication carriers, construct red culture communication network, and focus on communication effect on the basis of deeply excavating the value and connotation of red culture, so as to make due contribution to the great rejuvenation of Chinese Dream.

\section{ACKNOWLEDGMENT}

This work was supported by Liao cheng University doctoral initiation project (321052023) and Liaocheng philosophy and social science project. (Research on enhancing the international communication power of Liaocheng regional culture in the new era)

\section{REFERENCES}

[1] Xi Jinping. "win victory and build a moderately prosperous society in all respects, win the great victory of socialism with Chinese characteristics in the new era" - Report on the nineteenth National Congress of the Communist Party of China, China Guangming Daily October 28, 2017.

[2] YangMing.On the innovative expression of red culture in the new era. School party building and Ideological Education,(08)2021 pp.91-93

[3] XieXinThe application of red culture in the construction of youth culture. culture industry,(10)2021pp.132-134

[4] Zhang MeiLing.Analysis of red culture transmission path in tiktok short video.economist,(03)2021.pp3536

[5] Cai Zhonghua.Four dimensions of carrying forward patriotism since reform and opening up.Research on socialist core values,(02)2019

[6] Li CaiHong.Research on the integration of Long March film and television resources into socialist core values.Journal of Anshun University,(22)2020pp.66-70

[7] ChenJing.Reconstruction of red film and television education path in all media era.Journal of Chongqing University of Posts and Telecommunications,(32)2020pp.73-80

[8] Yang Tingting.Research on red culture in film and television works in the new era.cinematic literature,(21)2019pp.28-31

[9] Lu Qing.On the challenges and opportunities faced by the red films and TV plays in the new media environment.Research on the power of communication,(03)2019pp.64 